\title{
Another case for diet restriction: TAp73- expressing medulloblastomas are stunted by glutamine withdrawal
}

\author{
Marco Napoli and Elsa R. Flores \\ Department of Molecular Oncology, Cancer Biology and Evolution Program, H. Lee Moffitt Cancer Center and Research Institute, \\ Tampa, Florida 33612, USA
}

\begin{abstract}
Medulloblastomas are among the most common malignant brain cancers in the pediatric population and consist of at least four distinct subgroups with unique molecular and genetic features and clinical outcomes. In this issue of Genes \& Development, Niklison-Chirou and colleagues (pp. 1738-1753) identify the p53 family member and p73 isoform TAp73 as a crucial factor causing glutamine addiction in aggressive medulloblastomas. Their findings pave the way for the use of glutamine restriction as an adjuvant treatment for TAp73-expressing medulloblastomas.
\end{abstract}

Medulloblastomas (MBs) are malignant brain tumors arising in the posterior fossa and typically occur in children and young adults. The current therapeutic regimen la combination of surgery, radiotherapy, and systemic chemotherapy) allows for an $85 \%$ 5-yr survival rate but results in significantly lower neurocognitive and neuroendocrine functions (Liu et al. 2017). Therefore, several efforts are being made to obtain more effective and less toxic treatments. A pivotal breakthrough came from large-scale genomic analyses indicating that MBs comprise at least four molecular subgroups (Wingless [WNT], Sonic hedgehog [SHH], group 3, and group 4), each characterized by specific genetic alterations and clinical outcomes (Northcott et al. 2011). WNT-associated MBs have the most favorable prognosis, possibly due to their secretion of WNT antagonists that impair the blood-brain barrier, making these MBs more susceptible to chemotherapy. On the other side of the spectrum are group $3 \mathrm{MBs}$, which are the most metastatic and deadly cases (Liu et al. 2017).

It has been proposed that the four molecular subgroups of $\mathrm{MB}$ could be classified further based on the presence of additional mutations. The best-investigated example is mutations in the tumor suppressor TP53 gene. Indeed, the presence or absence of mutant p53 stratifies the SHH-MBs, but not the other MBs, in cases with poor

[Keywords: medulloblastoma; p73; glutamine; metabolomics] Corresponding author: elsa.flores@moffitt.org

Article is online at http://www.genesdev.org/cgi/doi/10.1101/gad.306837. 117. and better prognosis, respectively (Zhukova et al. 2013). The prognostic value of TP53 in MBs prompted researchers to evaluate whether the other members of the p53 family (p63 and p73) could also be prognostic in MBs. In particular, p73 was reported to be overexpressed in MB tumors and cell lines, indicating a possible prosurvival role for p73 in these tumors (Zitterbart et al. 2007). This is in agreement with observations using mouse models indicating that $\mathrm{p} 73$ is required for the embryonic development of the central nervous system (Yang et al. 2000) and the maintenance of neural stem cell niches in the adult brain (Pozniak et al. 2002).

To clarify which among the several isoforms of the TP73 gene are expressed in MBs, Niklison-Chirou et al. (2017) analyzed RNA sequencing data from 240 human MBs, showing that TAp73 $\alpha$ is the predominant TP73 isoform in MBs and, importantly, that its levels are higher in aggressive MBs (group 3 and group 4) compared with either the other subgroups or normal cerebella. Remarkably, the investigators demonstrated that transient or stable down-regulation of TPp73 impairs MB cell growth and causes profound metabolic alterations, including decreased mitochondrial respiration rates and glycolytic capacity. This correlates with reduced expression of several metabolism-related TAp73 target genes, in line with the important role of TAp73 in controlling numerous metabolic processes, such as mitochondrial oxidative phosphorylation, the pentose phosphate pathway, and autophagy (Napoli and Flores 2013, 2017). Importantly, the most crucial of these down-regulated target genes is glutaminase 2 (GLS-2), which encodes for an enzyme hydrolyzing glutamine in glutamate that in turn will be used as a substrate for the TCA cycle and for the production of the antioxidant glutathione. Indeed, the overexpression of GLS-2 in TP73 knockdown MB cells is sufficient to rescue the metabolic defects due to TP73 down-regulation. As a consequence of this dependency on GLS-2 activity, MB

(C) 2017 Napoli and Flores This article is distributed exclusively by Cold Spring Harbor Laboratory Press for the first six months after the full-issue publication date (see http://genesdev.cshlp.org/site/misc/terms.xhtml). After six months, it is available under a Creative Commons License (Attribution-NonCommercial 4.0 International), as described at http:// creativecommons.org/licenses/by-nc/4.0/. 
cells with high levels of TAp73 are more sensitive to glutamine starvation compared with $\mathrm{MB}$ cells with lower levels of TAp73. Notably, this glutamine addiction is maintained in vivo, as demonstrated in a xenograft model in which MB tumor growth is decreased in mice fed with a glutamine restriction diet. More importantly, this diet synergizes with cisplatin (a chemotherapeutic drug commonly used to treat MB patients) in counteracting $\mathrm{MB}$ tumor growth and extending survival of the treated mice. Taken together, these data provide exciting evidence for an alternative and less toxic treatment for MB patients.

However, this tumor-suppressive effect of glutamine starvation is not observed exclusively in MBs. Indeed, it has been shown previously to be an effective treatment in other cancers, including glioblastoma multiforme, liposarcoma, and breast cancer (Still and Yuneva 2017). This broad efficacy of glutamine restriction has led to the generation of glutaminase inhibitors whose activity is currently being evaluated in early phase clinical trials in combination with either chemotherapeutic drugs (e.g., paclitaxel), inhibitors of metabolic pathways (e.g., everolimus), or immunotherapeutic agents (e.g., nivolumab) (Still and Yuneva 2017). Therefore, the data reported by Niklison-Chirou et al. (2017) may have profound implications for the management of patients with not only TAp73-expressing MBs but also other cancers overexpressing this TP73 isoform. To guarantee the successful translation of the investigators' crucial findings into the clinic, it is important to remember the lesson learned from clinical trials of targeted therapies: Selection of the subset of patients that can benefit from such therapy is essential. Therefore, the possible functional interactions between TAp73 and the genetic alterations commonly found in the different MB subgroups should be considered. In particular, given the important role of TP53 status on prognosis of $\mathrm{MB}$, and since mutant p53 proteins are known to bind and inhibit TAp73 (Walerych et al. 2012), is the TP53 mutation status relevant for the effectiveness of glutamine restriction? Furthermore, even though TAp73 exerts distinctive functions with respect to its family members (Napoli and Flores 2016), cellular metabolism is a process regulated by the whole p53 family at multiple levels (Napoli and Flores 2017). So, can glutamine restriction be affected by the expression of the other members of the p53 family? While the investigators provide elegant in vivo data indicating the role of TAp73 in MBs, further addressing these points will be crucial for the success of a glutamine restriction diet as an adjuvant treatment for MBs, especially those expressing TAp73.

\section{Acknowledgments}

E.R.F. is a National Cancer Institute Outstanding Investigator (R35CA197452), Moffitt Distinguished Scholar, and Scholar of the Leukemia and Lymphoma Society, the Rita Allen Foundation, and the V Foundation for Cancer Research. M.N. is a Cancer Prevention Research Institute of Texas-Translational Research in Multidisciplinary Program Scholar and was supported by a Research Training Award (RP140106) and a grant from the Cancer Prevention and Research Institute of Texas (RP150094).

\section{References}

Liu KW, Pajtler KW, Worst BC, Pfister SM, Wechsler-Reya RJ. 2017. Molecular mechanisms and therapeutic targets in pediatric brain tumors. Sci Signal 10: eaaf7593.

Napoli M, Flores ER. 2013. The family that eats together stays together: new p53 family transcriptional targets in autophagy. Genes Dev 27: 971-974.

Napoli M, Flores ER. 2016. Unifying the p73 knockout phenotypes: TAp73 orchestrates multiciliogenesis. Genes Dev 30: 1253-1254.

Napoli M, Flores ER. 2017. The p53 family orchestrates the regulation of metabolism: physiological regulation and implications for cancer therapy. Br J Cancer 116: 149-155.

Niklison-Chirou MV, Erngren I, Engskog M, Haglöf J, Picard D, Remke M, McPolin PHR, Selby M, Williamson D, Clifford SC, et al. 2017. TAp73 is a marker of glutamine addiction in medulloblastoma. Genes Dev (this issue). doi: 10.1101/ gad.302349.117.

Northcott PA, Korshunov A, Witt H, Hielscher T, Eberhart CG, Mack S, Bouffet E, Clifford SC, Hawkins CE, French P, et al. 2011. Medulloblastoma comprises four distinct molecular variants. J Clin Oncol 29: 1408-1414.

Pozniak CD, Barnabe-Heider F, Rymar VV, Lee AF, Sadikot AF, Miller FD. 2002. p73 is required for survival and maintenance of CNS neurons. J Neurosci 22: 9800-9809.

Still ER, Yuneva MO. 2017. Hopefully devoted to Q: targeting glutamine addiction in cancer. Br J Cancer 116: 1375-1381.

Walerych D, Napoli M, Collavin L, Del Sal G. 2012. The rebel angel: mutant p53 as the driving oncogene in breast cancer. Carcinogenesis 33: 2007-2017.

Yang A, Walker N, Bronson R, Kaghad M, Oosterwegel M, Bonnin J, Vagner C, Bonnet H, Dikkes P, Sharpe A, et al. 2000. p73-deficient mice have neurological, pheromonal and inflammatory defects but lack spontaneous tumours. Nature 404: 99-103.

Zhukova N, Ramaswamy V, Remke M, Pfaff E, Shih DJ, Martin DC, Castelo-Branco P, Baskin B, Ray PN, Bouffet E, et al. 2013. Subgroup-specific prognostic implications of TP53 mutation in medulloblastoma. J Clin Oncol 31: 2927-2935.

Zitterbart K, Zavrelova I, Kadlecova J, Spesna R, Kratochvilova A, Pavelka Z, Sterba J. 2007. p73 expression in medulloblastoma: TAp $73 / \Delta \mathrm{Np} 73$ transcript detection and possible association of $\mathrm{p} 73 \alpha / \Delta \mathrm{Np} 73$ immunoreactivity with survival. Acta Neuropathol 114: 641-650. 


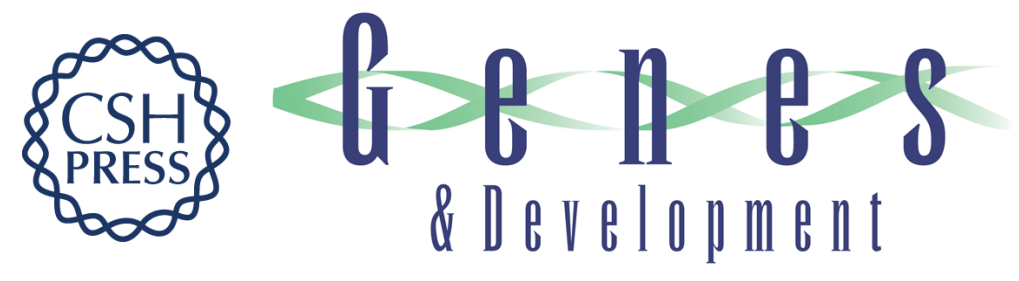

\section{Another case for diet restriction: TAp73-expressing medulloblastomas are stunted by glutamine withdrawal}

Marco Napoli and Elsa R. Flores

Genes Dev. 2017, 31:

Access the most recent version at doi:10.1101/gad.306837.117

$\begin{array}{ll}\text { Related Content } & \begin{array}{l}\text { TAp73 is a marker of glutamine addiction in medulloblastoma } \\ \text { Maria Victoria Niklison-Chirou, Ida Erngren, Mikael Engskog, et al. } \\ \text { Genes Dev. September, 2017 31: 1738-1753 }\end{array}\end{array}$

References This article cites 12 articles, 7 of which can be accessed free at: http://genesdev.cshlp.org/content/31/17/1715.full.html\#ref-list-1

Articles cited in: http://genesdev.cshlp.org/content/31/17/1715.full.html\#related-urls

Creative This article is distributed exclusively by Cold Spring Harbor Laboratory Press for the first Commons six months after the full-issue publication date (see License http://genesdev.cshlp.org/site/misc/terms.xhtml). After six months, it is available under a Creative Commons License (Attribution-NonCommercial 4.0 International), as described at http://creativecommons.org/licenses/by-nc/4.0/.

Email Alerting Receive free email alerts when new articles cite this article - sign up in the box at the top Service right corner of the article or click here.

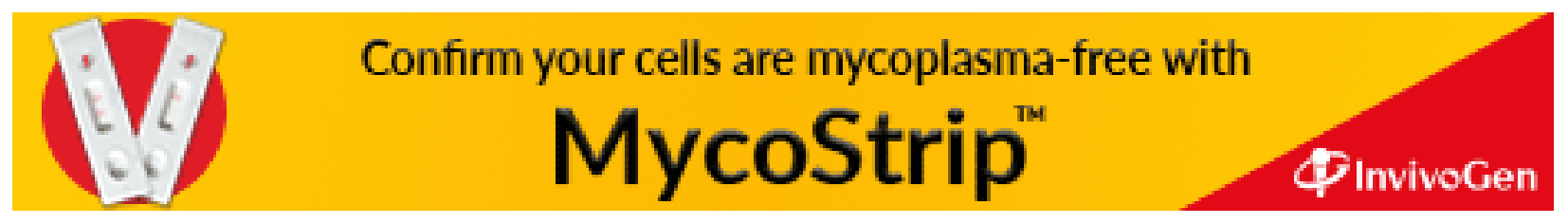

